堆 積 学 研 究, 56号, 27-39, 2003

J.Sed.Soc.Japan, No. 56, 27-39, 2003

\title{
宮城県仙台市北方の上部中新統番ヶ森山層, 青麻層の海流堆積相*
}

\section{吉田＼cjkstart真見子**立石＼cjkstart雅昭***}

\section{Ocean current-dominated sedimentary facies of the Upper Miocene Bangamoriyama and Aoso Formations to the north of Sendai, Miyagi Prefecture, Northeast Japan}

\section{Mamiko Yoshida** and Masaaki Tateishi***}

The Upper Miocene Bangamoriyama and Aoso Formations of the Shida Group are distributed to the north of Sendai, Miyagi Prefecture. These formations are composed of sandy sediments with large-scale trough and planer cross-stratifications. These formations unconformably overlies the Irisugaya Formation, and are unconformably overlain by the Nanakita Formation. These four formations are classified into eleven sedimentary facies, which are grouped into three facies associations (WS, OS, GS). These three facies associations respectively indicate wave-dominated shelf system (WS), ocean currentdominated shelf system (OS) and gravity flow-dominated shelf system (GS). Furthermore, this suggests that the study area was in a strait between the Abukuma and Kitakami Mountains, where a branch of a warm current flowed into during the deposition of the Bangamoriyama and Aoso Formations.

Key words: Aoso Formation, Bangamoriyama Formation, large-scale cross-stratifications, ocean current, sandwave, Upper Miocene

\section{はじめに}

宮城県仙台市の北方地域には，上部中新統の志苗 層群番ケ森山層・青麻層が分布している。これらの 地層は，最大波高 $6 \mathrm{~m}$ の大型斜交層理が発達した砂 質堆積物から構成される。番ヶ森山層の最大層厚は $120 \mathrm{~m}$ ，青麻層の最大層厚は $220 \mathrm{~m}$ に達する（北村 ほか，1983; 北村ほか，1986)。東北日本の上部中新 統でこのような岩相を示す地層は，仙台市北方地域 にその分布が限定され，きわめて特異な存在であ

受付: 2002 年 12 月 6 日 受理: 2003 年 3 月 10 日

* 堆積学研究会 2002 年春季研究集会 (岩手) にて一部講 演

** 新潟大学大学院自然科学研究科

Graduate School of Science and Technology, Niigata University, 2-8050 Ikarashi, Niigata, 950-2181, Japan

**** 新潟大学理学部地質科学科

Department of Geology, Faculty of Science, Niigata University, 2-8050 Ikarashi, Niigata, 950-2181, Japan
る，鳥越（1992）はこの大型斜交層理を形成した流 れが海流である可能性を指摘した。 しかし, 番ヶ森 山層・青麻層において堆積相・堆積システムの詳細 や海流の方向は検討されていない.

海流堆積物については，これまで海底調查による ベッドフォームの研究と陸域の地層での研究が行わ れている。海底調査によって海流により形成された と考えられているベッドフォームは，南アフリカの 東岸の陸棚上 (Flemming, 1978, 1980 ; Ramsay et al., 1996), 大隅海峡（池原ほか, 1988）, 隠岐海峡 (池原, 1991), 津軽海峡 (池原 - 佐藤, 1992), 神津 島・新島・三宅島周辺 (久保ほか, 2002) などで認 められている、亦た, 陸域の地層においては, 房総 半島上総層群市宿層 (中山・増田, 1987), 北海道樺 户山地南部一番川層（高野ほか，1995）で海流堆積 物の存在が認められている。しかし, 海流堆積物は 海底調査に比べ陸域での報告例が少ない，従って， 海流により形成されたと考えられる堆積物が分布す 
る本調査地域は, 数少ないフィールドの一つといえ る.

また，上部中新統において大型斜交層理の発達す る砂質堆積物が仙台市北方地域でのみ認められる理 由を解明することは, 東北日本の北上山地・阿武隈 山地・奥羽脊梁山地に囲まれた地域の古環境・古地 理を復元する上でも重要である.

この研究では番缶森山層・青麻層に加え, これら の下位及び上位の入菅谷層 - 七北田層の堆積相解析 を行い, 中期〜後期中新世の堆積環境について考察 した.さらに, 番ヶ森山層・青麻層堆積期の海流の 方向や仙台周辺地域の古地理の復元を行った.

\section{地 質 概 説}

宮城県の地質は南部北上帯・阿武隈帯の中・古生 界之，その他の地域に分布する第三系・第四系に区 分できる. 中・古生界は主に宮城県北東部之南部に 広く分布するが, 一部西部と中部（利府町周辺）に あ分布する（中川ほか，1989）。

調查地域は宮城県の中部に位置する大和町から 大郷町, 利府町に抢よぶ東西約 $3 \mathrm{~km}$, 南北約 $8 \mathrm{~km}$ の範囲である (Fig. 1). 調查地域を含む仙台・松島 地域周辺には, 中〜上部中新統志田層群が広く分布 し, 古くから層序学的研究がなされている（Hanzawa et al., 1953 ; 増田, 1957 ; 秋葉ほか, 1982 ; 石 井ほか，1982；北村ほか，1983; 北村ほか，1986）. 志田層群は下位の先新第三系 (三畳系利府層など), および下〜中部中新統松島湾層群を不整合に覆って いる（北村ほか, 1986). 志田層群を構成する地層名 は仙台北部地域（富谷地域周辺）と松島地域で異な り（Fig. 2), 調查地域を含む仙台北部地域では下位 加ら中部中新統の入菅谷層（層厚約 $50 \mathrm{~m}+$ ), 上部 中新統の番ヶ森山層（層厚 30 $120 \mathrm{~m}$ ), 青麻層 (層 厚 20〜220 m), 七北田層（層厚 50～200 m) に区分 されている(北村ほか, 1983 ; 北村ほか, 1986). 層 序関係は入菅谷層と番ヶ森山層が不整合関係，番ヶ 森山層と青麻層が整合関係である（北村ほか, 1983 ; 北村ほか, 1986). 従来, 青麻層と七北田層は整合 関係と考えられてきたが（北村ほか，1983; 北村ほ か, 1986), 松島地域の珪藻化石層序加 ら, 青麻層に 相当する呀る番ヶ森山層上部と七北田層に相当する 大松沢層が不整合関係にあることが明らかにされた (柳沢・秋葉, 1999). 従って, この研究では青麻層 と七北田層を不整合関係と考える. 地層の年代は松 島地域の珪藻化石帯から, 入菅谷層に相当する幡谷
層・鹿島台層が 12.3-12.9 Ma，番ヶ森山層・青麻層 に相当する番ヶ森山層が 9.5-10.0 Ma の範囲内，七 北田層に相当する大松沢層が 8.6-8.4 Ma と考えら れている（柳沢・秋葉，1999）。

以下に調査地域で認められる地層の特徽を示す (Fig. 3). 入菅谷層は凝灰質砂優勢砂岩泥岩互層で ある。層厚は約 $42 \mathrm{~m}$ 以上である。番ヶ森山層は大 型斜交層理が発達した軽石質の含礫粗粒〜極粗粒砂 岩から構成される。安山岩片や有色鉱物片を多く含 み，淘汰が悪い，層厚は約 $90 \mathrm{~m}$ である，青麻層は大 型斜交層理が発達した石英質の中粒〜粗粒砂岩から なり，砂の含有率などから砂碟質で淘汰の悪い下 部, 細粒で淘汰の良い中部, 粗粒で淘汰の良い上部 に細分できる. 下部の層厚は $20 \sim 40 \mathrm{~m}$, 中部の層厚 は 100〜 $160 \mathrm{~m}$ ，上部の層厚は $17 \sim 30 \mathrm{~m}$ である. 七 北田層は中碟岩を基底とし，淘汰の悪い塊状凝灰質 細粒〜極粗粒砂岩とシルト岩からなる. 層厚は約 19 $\mathrm{m}$ 以上である。

\section{堆積相区分}

堆積物の岩相, 堆積構造, 粒度, 淘汰度, 化石の 産状，生痕化石，生物擾乱，基底面の形状などの特 徵に基づき，入菅谷層・番ヶ森山層・青麻層・七北 田層において堆積相解析を行った。 その結果, 11 の 堆積相を認定した（Fig. 4). 主な柱状図は Figs. 5, 6 に示した.

\section{堆積相 1}

この堆積相は厚さ 1 20 cm の凝死質シルトと厚 さ $10 \sim 60 \mathrm{~cm}$ の中粒砂の互層汃らなり，層厚は 1 $1.5 \mathrm{~m}$ である。砂質部には波高 $30 \mathrm{~cm}$ 以下の斜交層 理が発達する. 生痕化石 (Ophiomorpha など) が多 く認められる.この堆積相は上方に向かって堆積相 4 に遷移する。

\section{堆積相 2}

この堆積相は中粒砂からなり, 層厚は $30 \sim 80 \mathrm{~cm}$ である. 塊状を呈し, 淘汰は比較的良い. 全体に多 くの生痕化石 (Ophiomorphaなど) が認められる. この堆積相は上方に向かって堆積相 3,4 に遷移す る.

\section{堆積相 3}

この堆積相は中粒〜粗粒砂からなり, 層厚は 50 $\mathrm{cm} \sim 4 \mathrm{~m}$ である. 波高 $50 \mathrm{~cm}$ 以下の小型のトラフ 


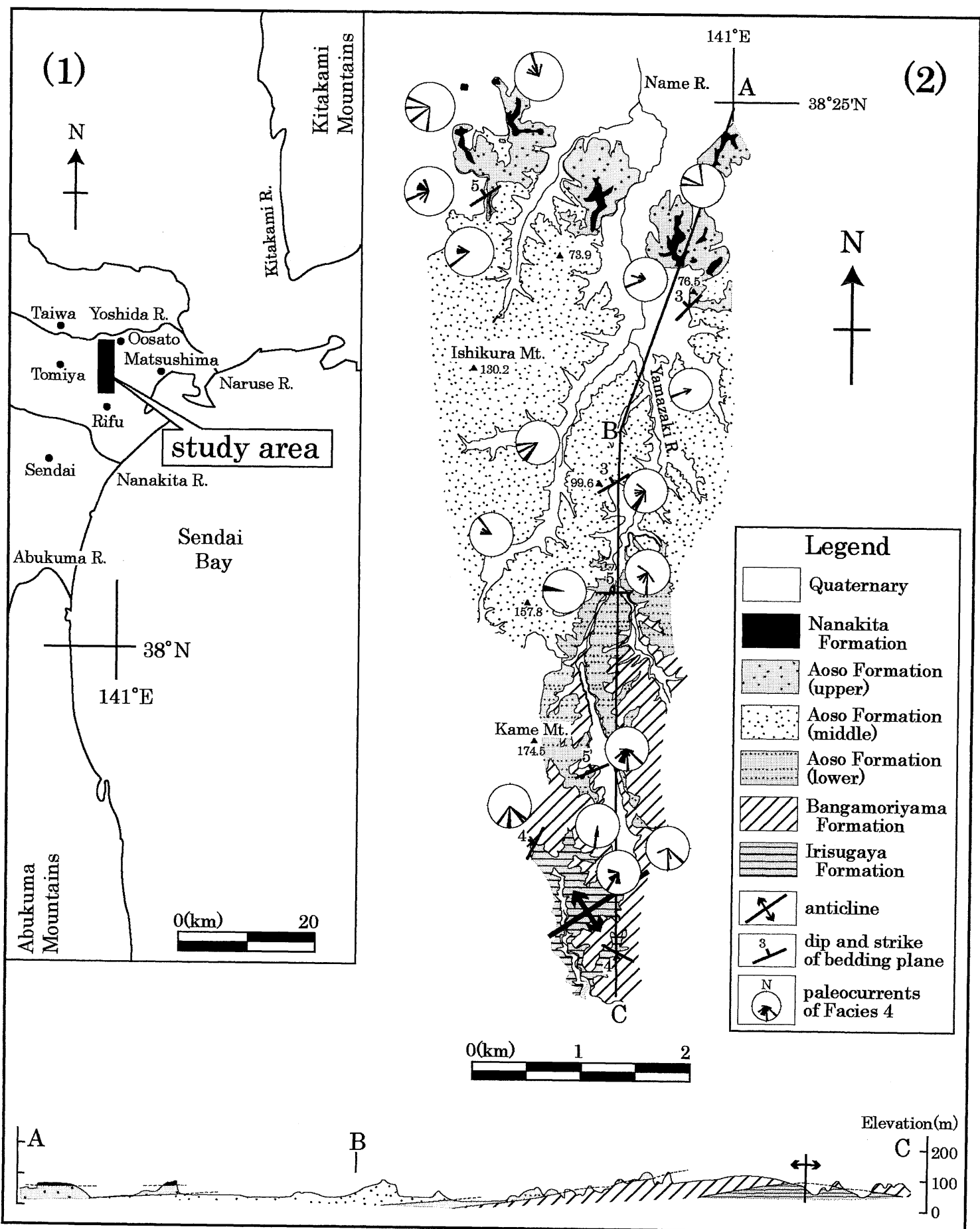

Fig. 1 (1) Index map of the study area.

(2) Geological map and geological cross sections of the study area. Rose diagrams indicate the direction of the paleocurrents of Facies 4. 


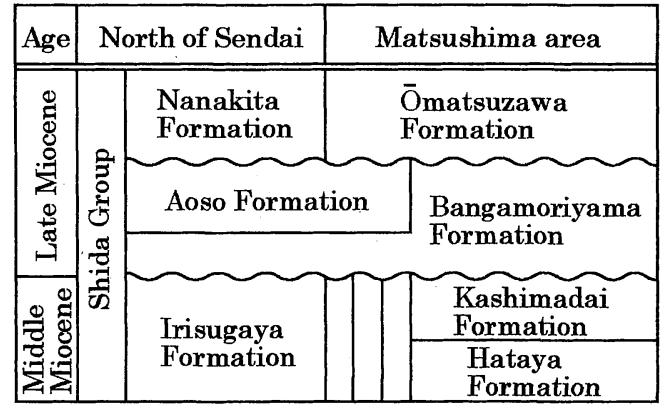

Fig. 2 Stratigraphy of the Shida Group in the north of Sendai and the Matsushima areas. Stratigraphy and geological ages are modified from Ishida et al. (1989).

〜プラナー状斜交層理が発達し，淘汰は良い。まれ に, マッドドレイプが認められる。生痕化石 (Ophiomorphaなど) が認められる.この堆積相は 上方に向かって堆積相 $1 ， 4$ （一部堆積相 5）に遷移 する

\section{堆積相 4}

この堆積相は中粒〜極粗粒砂からなり, 層厚は 50 $\mathrm{cm} \sim 6 \mathrm{~m}$ である. 層厚の側方变化が著しい. 波高 50 $\mathrm{cm} \sim 6 \mathrm{~m}$ の大型のトラフ〜プラナー状斜交層理が 発達し，上方ほど淘汰が良い。最下部には反流リッ プルが認められることもある，化石（サメの歯, 軟 骨魚類の椎体, 貝殼片等) を含み, 生痕化石 (Ophiomorphaなど） が認められる。この堆積相は上方に 向かって堆積相 2，3，4，5，6，10，11 に遷移する.

\section{堆積相 5}

この堆積相は粗粒〜極粗粒砂からなり, 層厚は 50 $\mathrm{cm} \sim 4 \mathrm{~m}$ である。細〜中碟を含んでいる．波高 20 $\mathrm{cm}$ 以下の小型のトラフ〜プラナー状斜交層理が発 達し, 淘汰は比較的悪い. 化石 (サメの歯, 軟骨魚 類の椎体, 硬骨魚類の椎体, 海生哺乳類の骨片, 貝 殻片など）を多数含んでいる。この堆積相は上方に 向かって堆積相 4,6 に遷移する.

\section{堆積相 6}

この堆積相は粗粒〜極粗粒砂からなり, 層厚は 25 $\mathrm{cm} \sim 1 \mathrm{~m}$ である. 細〜中礫を含んでいる. 不明瞭な 葉理が認められ, 淘汰は悪い. 化石 (サメの歯, 軟 骨魚類の椎体, 硬骨魚類の椎体, 海生哺乳類の骨片, 貝款片など）を多数含んでいる.この堆積相は上方

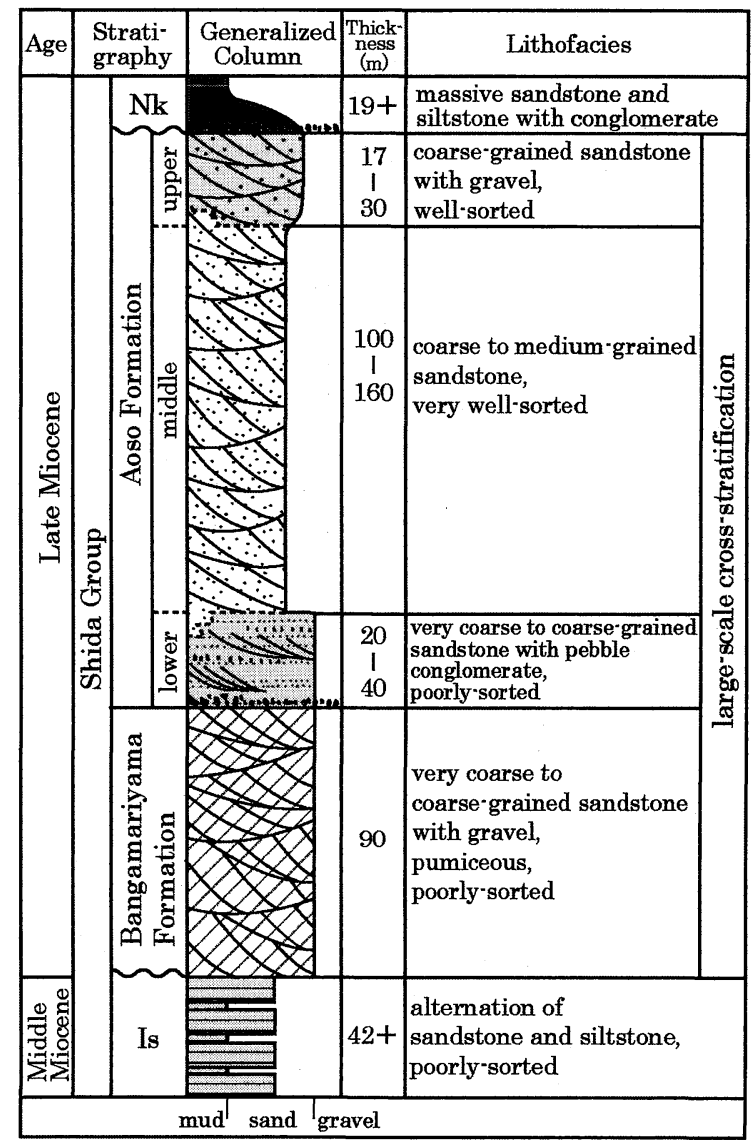

Fig. 3 Stratigraphy of the study area. Nk: Nanakita Formation, Is : Irisugaya Formation.

に向汃って堆積相 4, 5 （一部堆積相 3）に遷移する.

\section{堆積相 7}

この堆積相は凝灰質シルトからなり, 層厚は数 $\mathrm{cm} \sim 3 \mathrm{~m}$ である. 塊状を呈するが，一部に平行葉理 が認められる. 生物擾乱が発達し, 部分的に生痕化 石が密集する．化石（二枚貝化石）を含む．この堆 積相は上方に向かって堆積相 9 (一部堆積相 8) に遷 移する.

\section{堆積相 8}

この堆積相は細粒〜粗粒砂からなり, 層厚は 20 $\mathrm{cm} \sim 2 \mathrm{~m}$ である. 平行葉理・ハンモック状斜交層理 が発達し，一部にトラフ型斜交層理が認められる。 淘汰は比較的良い。上部にはシルトの薄層や複合流 リップル斜交層理が認められる。この堆積相は上方 


\begin{tabular}{|c|c|c|c|c|c|c|}
\hline $\begin{array}{l}\text { Facies } \\
\text { code }\end{array}$ & Block diagram & Lithofacies \& structure & $\begin{array}{l}\text { Sedimentary } \\
\text { environment }\end{array}$ & $\begin{array}{l}\text { Facies } \\
\text { associa }\end{array}$ & ation & System \\
\hline 1 & $\because \because \because \because$ & $\begin{array}{l}\text { alternation of siltstone and } \\
\text { medium-grained sandstone, } \\
\text { burrows }\end{array}$ & \multirow{7}{*}{ sand ridge } & \multirow{5}{*}{ 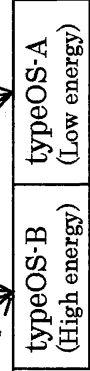 } & \multirow{5}{*}{0} & \multirow{5}{*}{ 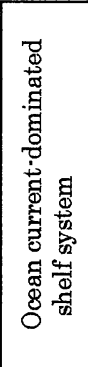 } \\
\hline 2 & & $\begin{array}{l}\text { medium-grained sandstone, } \\
\text { massive, } \\
\text { burrows }\end{array}$ & & & & \\
\hline 3 & & $\begin{array}{l}\text { small-scale cross'stratified } \\
\text { coarse to medium'grained } \\
\text { sandstone, burrows }\end{array}$ & & & & \\
\hline 4 & & $\begin{array}{l}\text { large-scale cross'stratified, } \\
\text { very coarse to } \\
\text { medium'grained sandstone }\end{array}$ & & & & \\
\hline \multirow{2}{*}{5} & \multirow{2}{*}{ 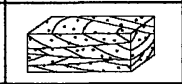 } & \multirow{2}{*}{$\begin{array}{l}\text { small'scale cross'stratified very } \\
\text { coarse to coarse'grained } \\
\text { sandatone with gravel }\end{array}$} & & & & \\
\hline & & & & \multirow{4}{*}{\multicolumn{2}{|c|}{ WS }} & \multirow{4}{*}{ 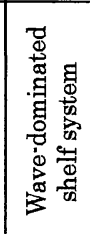 } \\
\hline 6 & 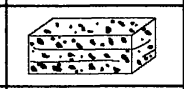 & $\begin{array}{l}\text { massive or laminated very } \\
\text { coarse to coarse-grained sand- } \\
\text { stone with gravel, poorly sorted }\end{array}$ & & & & \\
\hline 7 & & $\begin{array}{l}\text { massive or parallel laminated } \\
\text { siltstone, tuffaceous, } \\
\text { bioturbation }\end{array}$ & \multirow{6}{*}{$\begin{array}{l}\text { inner } \\
\text { shelf }\end{array}$} & & & \\
\hline \multirow{2}{*}{8} & \multirow{2}{*}{ : } & \multirow{2}{*}{$\begin{array}{l}\text { hummocky cross"stratified or } \\
\text { parallel laminated coarse to } \\
\text { fine-grained sandstone }\end{array}$} & & & & \\
\hline & & & & \multirow{4}{*}{\multicolumn{2}{|c|}{ GS }} & \multirow{4}{*}{ 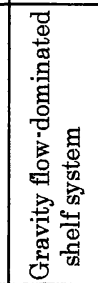 } \\
\hline 9 & & $\begin{array}{l}\text { coarse to very fine-grained } \\
\text { sandstone, poorly sorted, } \\
\text { massive, bioturbation }\end{array}$ & & & & \\
\hline 10 & $\because$ & $\begin{array}{l}\text { very coarse to coarse-grained } \\
\text { sandstone, dish structures } \\
\text { or massive, poorly sorted }\end{array}$ & & & & \\
\hline 11 & atsing & $\begin{array}{l}\text { pebble conglomerate, } \\
\text { grading, imbrication, } \\
\text { poorly sorted }\end{array}$ & & & & \\
\hline
\end{tabular}

Fig. 4 Facies classification of the Irisugaya, Bangamoriyama, Aoso and Nanakita Formations.

に向かって堆積相 7 （一部堆積相 9）に遷移する.

\section{堆積相 9}

この堆積相は凝灰質極細粒〜粗粒砂からなり，層 厚は $6 \mathrm{~m}$ 以下である. 細礫やシルトの偽磁を含み, 淘汰が悪い．塊状を呈する．生物擾乱や生痕化石が 多く認められる。この堆積相は上方に向かって堆積 相 7, 8（一部堆積相 4）に遷移する.

\section{堆積相 10}

この堆積相は凝灰質粗粒〜極粗粒砂からなり，層 厚は 5〜10 m である.細〜中礫，一部に巨礫を含ん でいる，塊状，または皿状構造（Lowe，1975）が発 達している. 淘汰は悪い. 生物擾乱が認められ, 化 石 (サメの歯, 貝殻片) を含んでいる.この堆積相 は上方に向かって堆積相 9,11 に遷移する.

\section{堆積相 11}

この堆積相は中礫からなり，一部に巨礫を含んで いる。層厚は $10 \mathrm{~m}$ 以下である。基質は淘汰の悪い 粗粒～極粗粒砂からなる。級化構造が認められる. 弱い斜交層理，またはインブリケーションが認めら
れることあある. 化石 (サメの歯, 軟骨魚類の椎体, 硬骨魚類の椎体, 海生哺乳類の骨片, 具壳片など) を多数含んでいる。この堆積相は上方に向かって堆 積相 10 （一部堆積相 4）に遷移する.

\section{堆積相の分布と古流向}

入菅谷層は堆積相 7，8，9 から構成される（Fig. 5). 堆積相 8 の複合流リップル斜交層理から求めた 古流向は，北方向への流れを示している（Fig. 5 の 柱状図 14，15)。

番ヶ森山層は堆積相 $4,5,6$ から構成される (Fig. 5). 堆積相 4 の古流向は, 南方向への流れを 示している (Figs. 1，5). 堆積相 5 の古流向は, 堆 積相 4 同様に南方向が卓越するが，他方向も認めら れる。

青麻層下部は堆積相 4，5，6，11 から構成される (Fig. 5). 堆積相 4 の古流向は，南〜南西方向への 流れを示している（Figs. 1，5）.

青麻層中部は主に堆積相 $1 ， 2 ， 3 ， 4$ (一部堆積相 5）から構成される (Figs. 5，6). 堆積相 4 の古流向 は，西方向への流れを示している（Figs. 1，5，6）。 堆積相 3,5 の古流向は, 西方向への流れが卓越する 


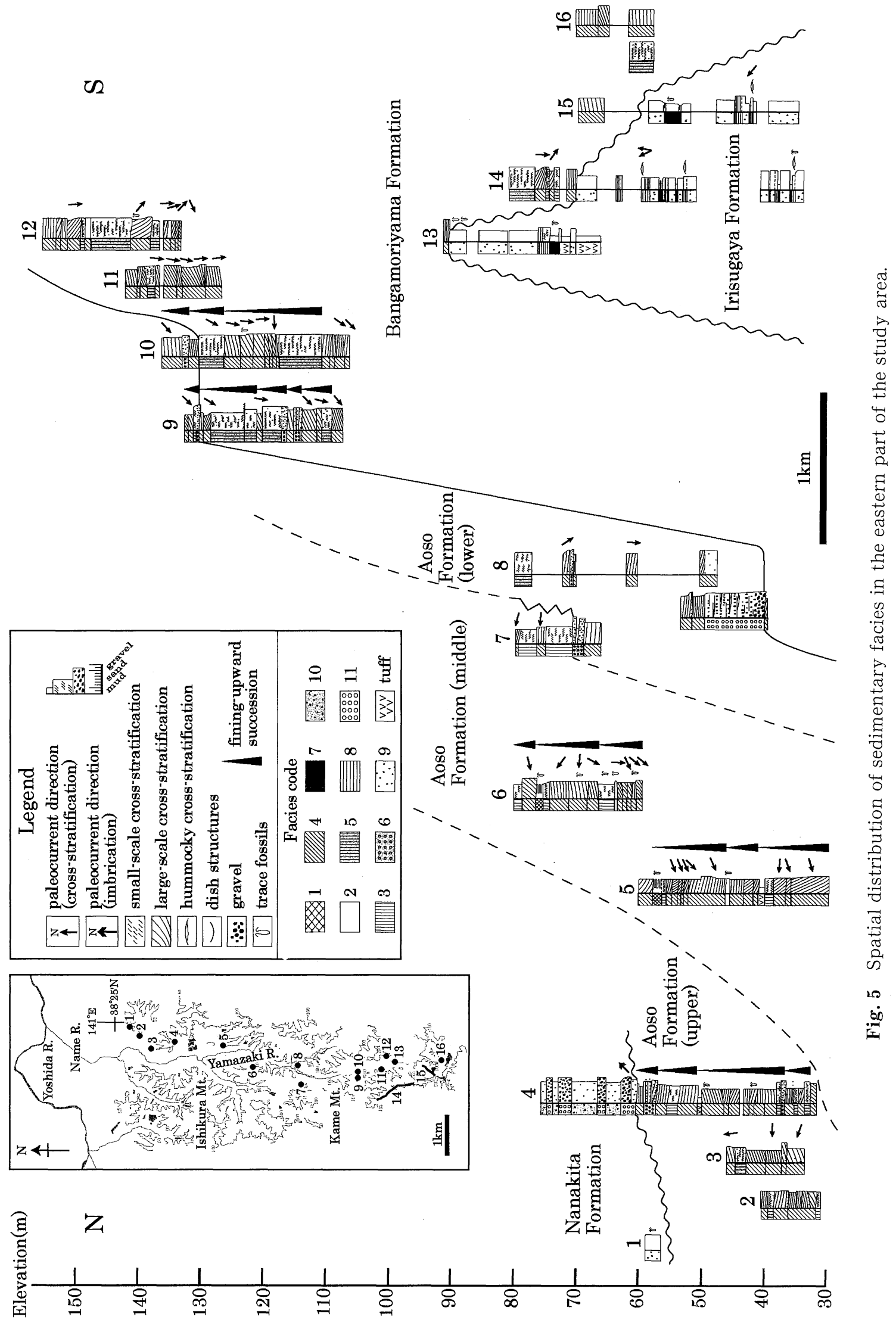




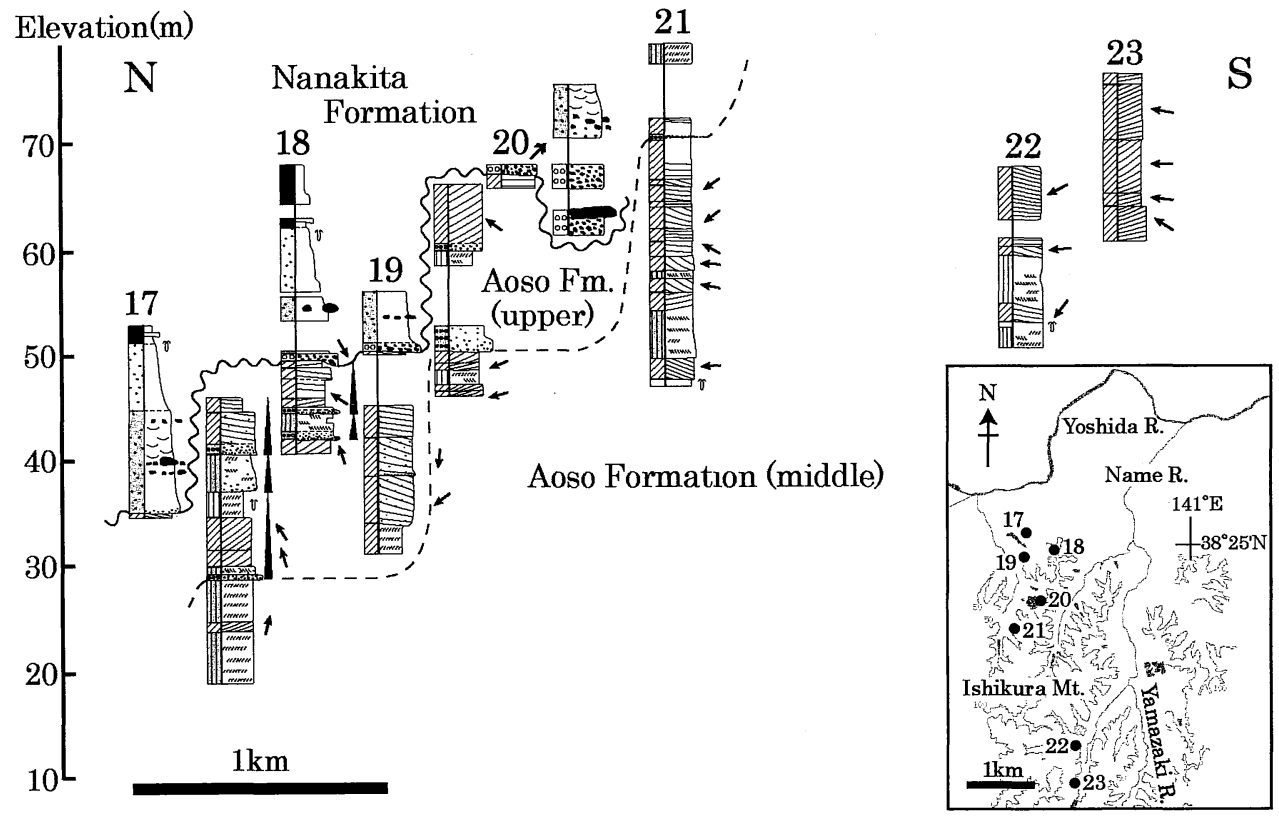

Fig. 6 Spatial distribution of sedimentary facies in the western part of the study area. For legend see Fig. 5.

が，他方向も認められる。

青麻層上部は主に堆積相 $3 ， 4 ， 5 ， 6$ から構成され る (Figs. 5，6)。堆積相 4 の古流向は, 西方向への 流れを示している（Figs. 1，5，6）。堆積相 3，5の 古流向は，西方向への流れが卓越するが，他方向も 認められる。

七北田層は堆積相 7，9，10，11 から構成される (Figs. 5，6). 堆積相 11 のインブリケート構造や斜 交層理から求めた古流向は, 東方向への流れを示し ている（Figs. 5，6の柱状図 4，18，20）.

\section{堆積組相と堆積システム}

11 の堆積相は，それらの遷移関係に基づいて $3 つ$ の堆積組相 WS・OS・GSにまとめることができた (Fig. 4). 3つの堆積組相は, それぞれ別個の堆積シ ステムである波浪卓越型陸棚システム・海流卓越型 陸棚システム・重力流卓越型陸棚システムを示して いる.

\section{1. 堆積組相 WS : 波浪卓越型陸棚システム}

\section{(1) 堆積組相}

堆積組相 WS は堆積相 7, 8, 9 から構成されてい る（Fig. 4)。これらは下位から堆積相 9，8，7 と重 なる。この堆積組相は入菅谷層で認められる（Fig.
5).

\section{（2）堆積システム}

堆積相 8 はハンモック状斜交層理などの波浪の堆 積構造が認められること, 一部で内部に薄いシルト 相を挟在することから，内側陸棚の堆積物と考えら れる (斉藤, 1989 ; Walker and Plint, 1992). 堆積 相 7 は下位の堆積相 8 から遷移するなど，堆積相 8 と密接に関連して発達することや比較的砂質である ことから, 内側陸棚の泥質堆積物と推定される。 ま た, 堆積相 9 は不淘汰塊状の砂から構成され, 陸棚 上に発生した重力流堆積物と考えられる。

以上から，堆積組相 WS は波浪卓越型陸棚システ ムを示している。

\section{2. 堆積組相 OS : 海流卓越型陸棚システム}

\section{(1) 堆積組相}

堆積組相 OS は堆積相 $1 ， 2 ， 3 ， 4 ， 5 ， 6$ と一部堆 積相 11 から構成される (Fig. 4).これらは約 5 10 $\mathrm{m}$ ごとに 2 つの異なるタイプの上方細粒化を示す. タイプ OS-A は下位から堆積相 4，3，1，または堆積 相 4,2 と重なる組み合わせからなり, 上位に向かっ て生痕化石が増加する。このタイプは青麻層中部で 認められる (Fig. 5 の柱状困 5，6)。タイプ OS-B は 下位汃ら堆積相 6，5，4，または堆積相 6，5，4，3 


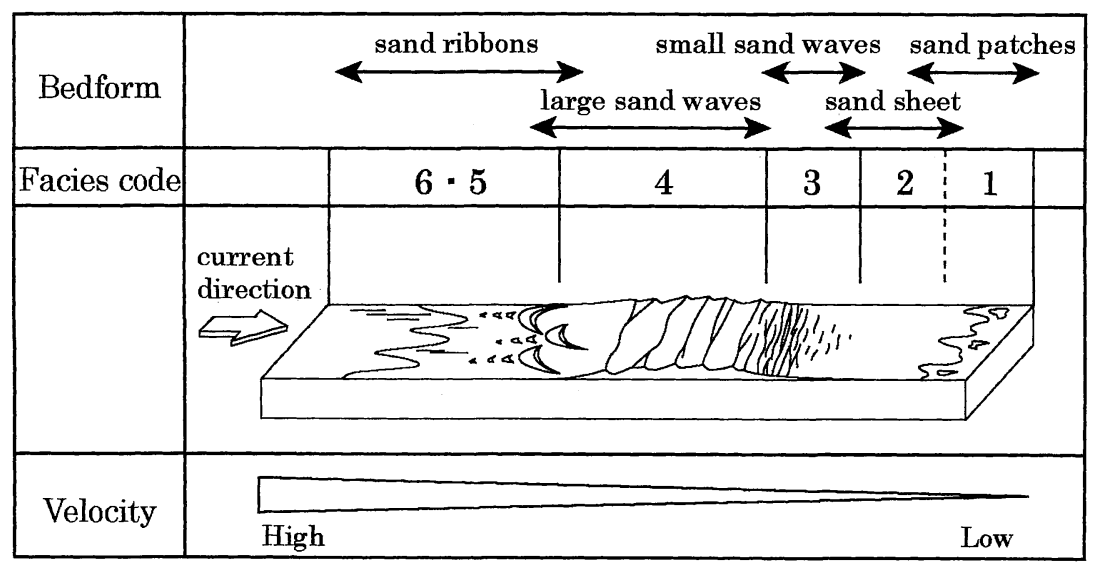

Fig. 7 Relationship between the Facies code (present study), flow regime and bedforms made by tidal and ocean currents. Bedform arrangement is modified from Belderson et al. (1982) and Ikehara et al. (1988).

と重なる組み合わせからなる。このタイプは番ヶ森 山層・青麻層下部・青麻層上部で多く認められる (Figs. 5，6の柱状図 4，9，18). また，堆積相 11 は 一部の地域で青麻層の基底に認められる（Fig. 5 の 柱状図 8).

\section{（2）堆積システム}

堆積相 4 は最大波高 $6 \mathrm{~m}$ の大型斜交層理を示し, サンドウェーブに相当する（McCave，1971; 池原 ほか，1988）。堆積相 4 は上下・側方関係で堆積相 1 ～6 と密接に関連して発達し（Figs. 5，6），厚い砂 質堆積物を作っている.これらの堆積相の違いは, 主に流れのエネルギー条件の違いを反映していると 考えられる，つまり，サンドウェーブに相当する堆 積相 4 を中心に考えると, 粗粒で掏汰の悪い堆積相 5，6 はより高いエネルギー条件下で，細粒で生痕化 石が多く認められる堆積相 1，2，3 はより低いエネ ルギー条件下で堆積したと考えられる. 従って, 夕 イプ OS-A や OS-B で認められる上方細粒化する堆 積相の遷移は，流れのエネルギー条件の減少を反映 していることがわかる.

Belderson et al. (1982) はサンドウェーブを中心 とした一連のベッドフォームを潮流の流速に対応さ せてモデル化している（Fig. 7)。すなわち，サンド リボン, サンドウェーブ, サンドシート, サンド パッチが潮流の流速の減少に対応して配列している (Belderson and Stride, 1966; Belderson et al., 1982).このベッドフォームの配列は, 海流において あ同様に報告され，さらに底質むその方向に細粒化 することがわかっている（池原ほか，1988；Ike- hara，1993).これらによると, 堆積相 5，6 のよう に砂質で粗粒な堆積相は，高いエネルギー領域で認 められるサンドリボンに相当する (Fig. 7). 堆積相 4 のように大型斜交層理が発達した堆積相は，小型 〜大型のサンドゥェーブに相当する (Fig. 7). 堆積 相 3 のように小型斜交層理が発達する堆積相は，小 型のサンドウェーブ〜サンドシートに相当する (Fig. 7). 堆積相 2 のように生痕化石が多く認めら れ塊状の堆積相や堆積相 1 のように砂や泥汃らなる 堆積相は，より低いエネルギー領域で認められるサ ンドシート〜サンドパッチに相当する（Fig. 7).

次に，堆積環境とサンドウェーブ堆積物を形成し た流れについて考察する，底生有孔虫化石群集加 ら，青麻層は中〜外部浅海帯に堆積したことが明ら かにされている（北村ほか，1986）。中川ほか（1989） によると，太平洋における中～外部浅海帯の深度は 70〜180 $\mathrm{m}$ と考えられている。 そして，番ヶ森山 層・青麻層に相当する周辺地域の地層が砂質堆積物 であることから（石田ほか，1989），番ヶ森山層・青 麻層のサンドウェーブ堆積物は比較的浅い陸棚環境 で堆積したと推定される。

Ikehara and Kinoshita（1994）は日本周辺の陸棚 上に発達するサンドウェーブ（波長 $10 \mathrm{~m}$ 以上，波 高 $0.75 \mathrm{~m}$ 以上=大型水成デューン）を潮流卓越型 環境の豊後水道, 備讃海峡, 関門海峡，または海流 卓越型環境の大隅海峡，隠岐海峡，津軽海峡なごで 報告している。これによると，サンドウェーブ堆積 物は主に潮流や海流によって海峡部などで形成され ている，以上を考慮して, 調査地域のサンドウェー 
(a) Irisugaya Formation

(b) Bangamoriyama Formation

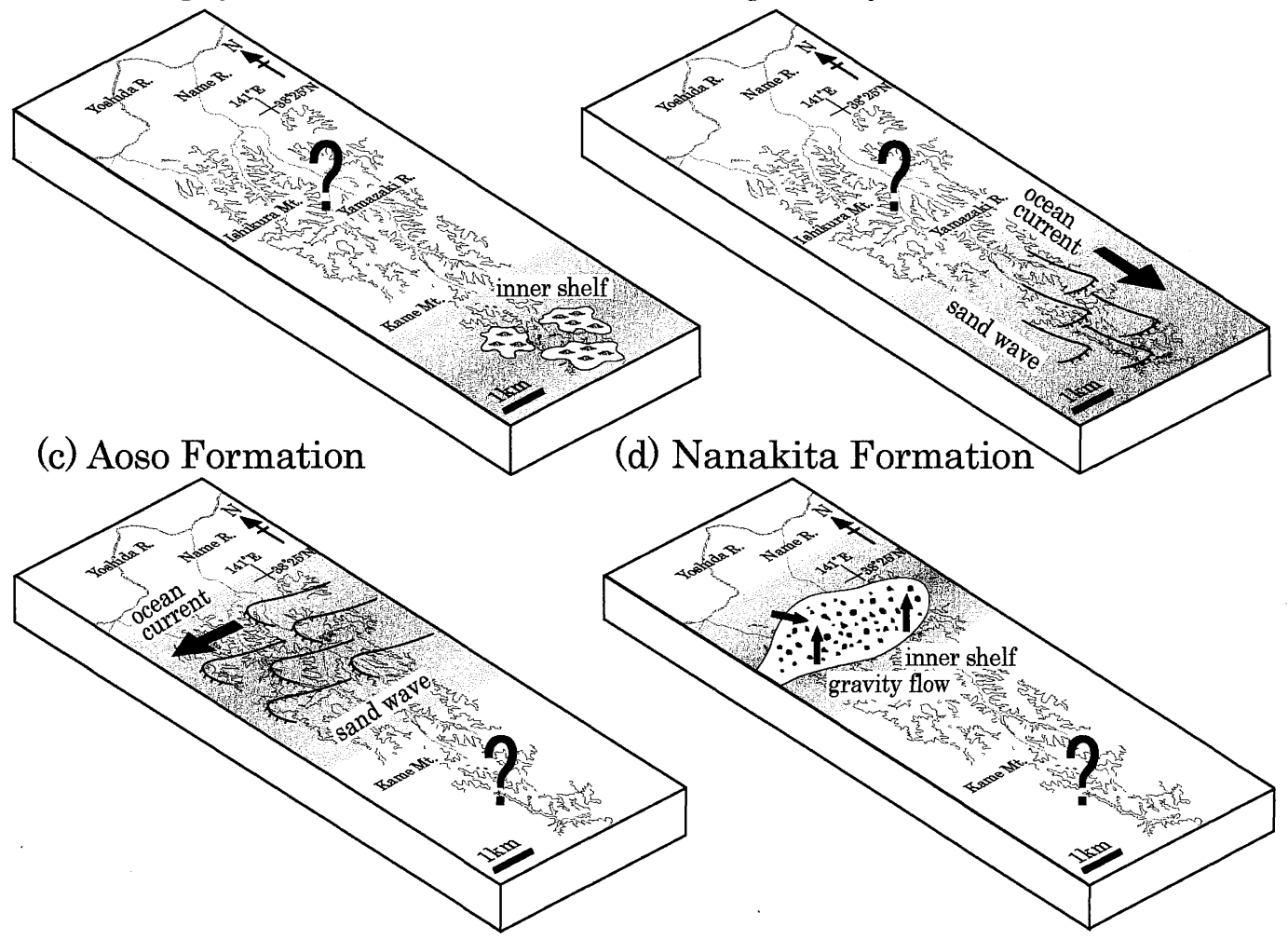

Fig. 8 Reconstruction of depositional environments during the deposition of the Irisugaya Formation (a), Bangamoriyama Formation (b), Aoso Formation (c) and Nanakita Formation (d) in the study area. Arrows show the paleocurrents.

ブ堆積物の特徵を述べる. 調査地域の大型斜交層理 の古流向は番ヶ森山層で南方向への流れ, 青麻層で 西方向への流れを示し，一方向性の流れが卓越する (Fig. 1)。そして，大型斜交層理にはマッドドレイ プが認められず, Allen (1980) のサンドウェーブや デューンの内部構造分類の CLASS A と I A タイ プが卓越する。また，サンドウェーブ堆積物からな る番ヶ森山層・青麻層の最大層厚はそれぞれ 120 $\mathrm{m}, 220 \mathrm{~m}$ に達し，一定の強い流れにより形成され たことがわかる。これらの特徵は, 調査地域のサン ドウェーブ堆積物が一方向性の流れである海流によ り形成されたことを示している。しかし，堆積相 3, 5 の小型斜交層理で求められた古流向は, 大型斜交 層理之同様に番ヶ森山層で南方向への流れ, 青麻層 で西方向への流れが卓越するが，他方向への流れも 含んでいる。一般に, ヘリンボーン構造のような逆 方向の古流向が認められると, 潮汐作用の影響を受 けていた可能性が高いと考えられている（Dalrym- ple, 1992). しかし, 海流卓越型環境である大隅海 峡のサンドウェーブの古流向は海流の方向之調和的 であるが，リップルマークの古流向は一定しないこ とがわかっている（池原ほか，1988）。上述したよう に, 調査地域で認められる他方向を示す古流向は小 型斜交層理に限定されることから，番ヶ森山層・青 麻層のサンドウェーブ堆積物は一方向性の流れであ る海流が卓越する環境で形成されたと推定できる。

また, 堆積相 11 は一部の地域でのみ認められ, 不 淘汰な中礫相から構成されるため, 一時的に海流の 卓越する陸棚に流れ下った重力流堆積物と考えられ る.

以上から，堆積組相 OS は海流卓越型陸棚システ ムを示している.

\section{3. 堆積組相 GS : 重力流卓越型陸棚システム (1) 堆積組相}

堆積組相 GS は堆積相 7, 9, 10,11 から構成され 


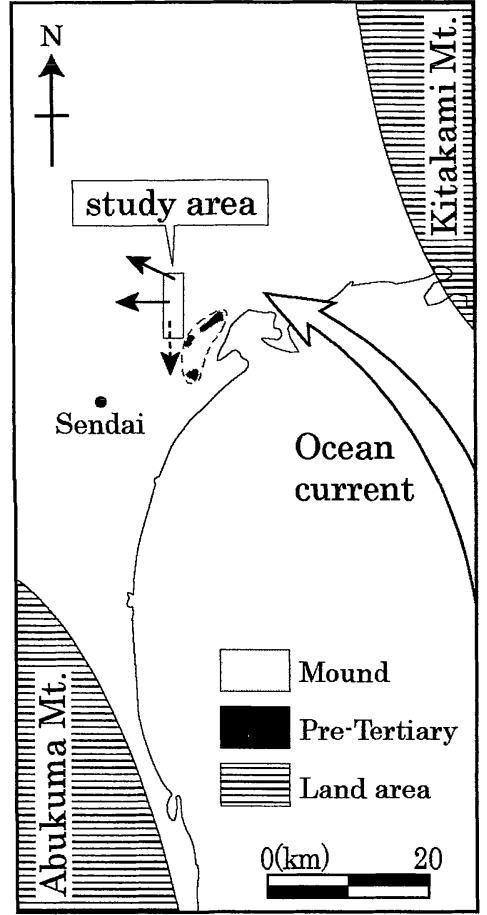

Fig. 9 Paleogeographic map in the Late Miocene in the Sendai area. White arrow shows inferred ocean current. Solid arrows show the paleocurrents of the Aoso Formation. Dashed arrow shows the paleocurrent of the Bangamoriyama Formation. Solid line shows the present shoreline. Land area is from Kano et al. (1991).

ている (Fig. 4)。これらは下位から堆積相 11，10， 9, 7 と重なる.この堆積組相は七北田層で認められ る (Figs. 5, 6).

\section{（2）堆積システム}

堆積相 9, 10, 11 は基本的に不淘汰塊状で, 磁相 から砂相に級化するユニットの繰り返しから構成さ れるため, 重力流堆積物と推定できる. 堆積相 11 は 級化構造が認められる淘汰の悪い中礫から構成され るため, Lowe (1982) の R2 に相当する. 堆積相 9, 10 は塊状, 屯しくは血状構造の発達した砂から構成 されるため, Lowe (1982) の S3 に相当する.よっ て, 堆積相 9, 10, 11 は高密度混濁流堆積物 (Lowe，1982）と考えられる。 また，堆積相 9，10， 11 は海生化石を多産すること, 堆積相 7 と関連して 存在することから, 陸棚上に発達した重力流堆積物 と推定できる。
以上から, 堆積組相 GS は重力流卓越型陸棚シス テムを示している.

\section{堆積環境の変遷と古地理}

堆積システムの復元をあとに, 各層準堆積期ごと の堆積環境をまとめると以下のような変化が認めら れる. 入菅谷層堆積期 (約 $12 \mathrm{Ma}$ ) には, 調査地域に 海流の影響はまだ無く，比較的穏やかな内側陸棚の 環境が広がっていた（Fig. 8-a）。番ヶ森山層堆積期

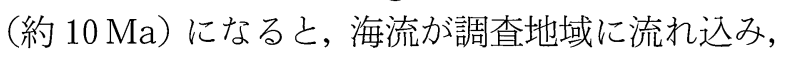
サンドウェーブ堆積物を形成した（Fig. 8-b).この 時期の調査地域は，海流のエネルギーが高い領域に あったと推定される. 青麻層堆積期にも引き続き海 流が流れ込み, サンドウェーブ堆積物を形成した (Fig. 8-c). 青麻層下部堆積期には海流のエネル ギーが高い領域にあったが，中部堆積期には低い領 域に变化した。 そして, 上部堆積期には再び高い領 域に変化したと推定される。七北田層堆積期（約 8 Ma）になると海流の影響は無くなり, 奥羽春梁山地 の陸化に伴って形成されたデル夕の崩壊により, 西 方から重力流が流れ込んでいたと考えられる（Fig. 8-d).

次に, 番ヶ森山層・青麻層堆積期である約 $10 \mathrm{Ma}$ の仙台周辺地域の古地理を考察する。鹿野ほか （1991）によると，約 $10 \mathrm{Ma}$ の東北日本は北上山 地・阿武隈山地・奥羽脊梁山地の一部が陸域となっ ていたものの，仙台周辺地域を含むその他の地域で 海が広がっていたと考えられている。このことは仙 台周辺地域が北上山地と阿武隈山地の間に挟まれた 海峡のような場所に位置していたことを示してい る.

また，後期中新世において，東北日本の太平洋側 は寒流の影響下にあったと考えられているが（Oda et al., 1984), 青麻層加ら産出した浮遊性有孔虫化石 群集は暖海性種が卓越し, 暖流の影響下にあったこ とがわかっている (Saito and Isawa，1995). そし て, 本研究結果により, 番ヶ森山層・青麻層は海流 堆積物と解釈できること, 青麻層のサンドウェーブ の古流向は西方向への流れを示すことが明らかと なった. 以上から, 約 $10 \mathrm{Ma}$ の仙台周辺地域は北上 山地と阿武隈山地に挟まれた海峡部に位置し，この 海峡に暖流の分岐が流れ込んでいたと推定される (Fig. 9).

しかし，番ヶ森山層のサンドウェーブの古流向は 南方向への流れを示している。これについては以下 
のように考察した。番ヶ森山層分布域の南東部には 先新第三系が分布しており，番ヶ森山層の古流向が この先新第三系に沿うように南方向への流れを示し ている (Fig. 9).このことは先新第三系が当時から 地形的高まりとして存在していたために，この高ま りに沿って流れが変化したことを示唆する（Fig. 9). 大隅半島と種子島の間に位置する大隅海峡にお いて，サンドウェーブの古流向は海流と調和的な北 東方向への流れが主流であるが，種子島周辺のサン ドウェーブの古流向はこの地形に沿うように東へ向 かう流れに変化している（池原ほか，1988；Ike-

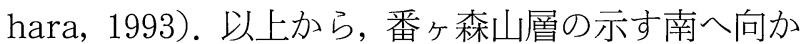
う古流向は，海流が当時の地形に規制されて流れた 結果と考えられる。

\section{ま と め}

宮城県仙台市の北方地域に分布する中～上部中新 統志田層群入菅谷層・番ヶ森山層・青麻層・七北田 層において堆積相解析を行い，堆積システムの復元 を行った。 その結果, 以下の事項が明らかとなった。 （1）調査地域に分布する入菅谷層・番ヶ森山層・ 青麻層・七北田層は, 11 の堆積相之 3 つの堆積組相 (WS・OS・GS）に区分できる．堆積組相はそれ ぞれ波浪卓越型陸棚システム $(\mathrm{WS}) \cdot$ 海流卓越型陸 棚システム $(\mathrm{OS}) \cdot$ 重力流卓越型陸棚システム (GS) を示している.

（2）各層に認められる堆積システムの分布から, 中部中新統の入菅谷層は波浪卓越型陸棚システム, 上部中新統の番ヶ森山層・青麻層は海流卓越型陸棚 システム，七北田層は重力流卓越型陸棚システムで 形成されたことがわかった。ささらに，海流堆積物中 に流速の減少を反映していると考えられる約 $5 \sim 10$ $\mathrm{m}$ ごとの上方細粒化の重なりがあることを示した. また，番ヶ森山層と青麻層下部・上部は海流のエネ ルギーが高い領域で，青麻層中部は低い領域で堆積 したことがわかった。

（3）青麻層が暖流の影響下にあったと考えられる こと (Saito and Isawa, 1995)，青麻層の古流向が西 方向への流れを示すことなどから，番ヶ森山層・青 麻層堆積期の仙台周辺地域は，北上山地之阿武险山 地に挟まれた海峡部に位置し，この海峡に暖流の分 岐が流れ込んでいたという古地理を復元した。そし て，番ヶ森山層の南へ向かう古流向は，海流が当時 の地形に規制されて流れた結果と考察した。

\section{謝辞}

この研究を進めるにあたり, 新潟大学積雪地域災 害研究センターのト部厚志助教授には終始ご指導を いただいた。新潟大学の小林嚴雄名誉教授，同大学 自然科学研究科の矢部英生氏には現地での討論なら びに海生動物化石の同定をしていただいた。石油資 源開発株式会社の浜田康史氏，竹花康夫氏，高野 修氏，東 将士氏には現地での討論を通して有益な ご意見をいただいた。信州大学の保柳康一助教授に は貴重なご指摘をいただき，原稿が改善された。こ れらの方々に深く感謝いたします。

\section{文献}

秋葉文雄・柳沢幸夫 - 石井武政, 1982 : 宮城県松島周辺に分布す る新第三系の珪藻化石層序. 地調月報，33，215-239.

Allen, J. R. L., 1980 : Sand waves : a model of origin and internal structure, Sediment. Geol., 26, 281-328.

Belderson, R. H. and Stride, A.H., 1966 : Tidal current fashioning of a basal bed. Marine Geol., 4, 237-257.

Belderson, R. H., Johnson, M. A. and Kenyon, N. H., 1982 : Bedforms, In Stride, A. H., ed., Offshore Tidal Sands, Processes and Deposits, 27-57, Chapman and Hall, London.

Dalrymple, R.W., 1992 : Tidal depositional systems. In Walker, R.G. and James, N.P., eds., Facies Models : response to sea level change, 195-218, Geol. Ass. Can.

Flemming, B.W., 1978: Underwater sand dunes along the southeast African continental margin-observations and implications. Marine Geol., 26, 177-198.

Flemming, B. W., 1980 : Sand transport and bedform patterns on the continental shelf between Durban and Port Elizabeth (southeast African continental margin). Sediment. Geol., 26, 179-205.

Hanzawa, S., Hatai, K., Iwai J., Kitamura N., Shibata T., 1953 : The geology of Sendai and its environs. Sci. Rep. Tohoku Univ., 2nd ser. (Geol.), 25, 1-50.

池原 研，1991：隠岐海峡に見られるベッドフォーム：非活動的 ベッドフォームシステムの例. 堆積学研究会報, no. 35, 1928.

Ikehara, K., 1993 : Modern sedimentation in the shelf to basin areas around Southwest Japan, with special reference to the relationship between sedimentation and oceanographic conditions. Bull. Geol. Surv. Japan, 44, 283-349.

Ikehara, K. and Kinoshita Y., 1994 : Distribution and origin of subaqueous dunes on the shelf of Japan. Marine Geol., $120,75-87$.

池原 研 - 木下泰正 ・西村清和 - 中村光一 ・ 川幡穂高, 1988 : 大 隅海峡にみられるベッドフォームの形態と分布. 地調月報, 39, 95-113.

池原 研・佐藤幹夫, 1992 : 津軽海峡にみられる大型水成デュー 
ン (予報)。堆積学研究会報, no. 37, 53-58.

石田环二・中川久夫 - 生出慶司 - 竹内貞子, 1989 : 仙台地域. 生 出慶司・中山久夫・蟹沢聰史（編）日本の地質 2 東北地方, 119-127, 共立出版株式会社, 東京.

石井武政 - 柳沢幸夫 - 山口昇一・寒川 旭 - 松野久也, 1982 : 松 島地域の地質. 地域地質研究報告 (5 万分の 1 地質図幅), 地 質調査所, $121 \mathrm{p}$.

鹿野和彦 - 柳沢幸夫 - 加藤碵一 - 山元孝広 - 尾崎正紀 - 水野清 秀 - 渡辺 寧 - 渡邊真人, 1991 : 日本の新生界層序と地史 第一部 古地理と地史. 地質調査所報告, no. 274, 1-37.

北村 信 - 石井武政 - 寒川 旭 - 中川久夫, 1986 : 仙台地域の地 質. 地域地質研究報告 (5 万分の 1 地質図幅), 地質調查所, $134 \mathrm{p}$.

北村 信. 大沢 穠 - 中川久夫, 1983 : 吉岡地域の地質. 地域地 質研究報告 ( 5 万分の 1 図幅), 地質調查所, 50 p.

久保雄介・徐 垣 - 町山栄章 - 徳山英一, 2002 : 伊豆海嶺を越え る黒潮によるベッドフォーム: 神津島・新島・三宅島周辺 でのサイドスキャンソナーによる海底調査. 地質雑, 108 , 103-113.

Lowe, D. R., 1975 : Water escape structures in coarse-grained sediments. Sedimentology, 22, 157-204.

Lowe, D.R., 1982 : Sediment gravity flows : II. Depositional models with special reference to the deposits of highdensity turbidity currents. Jour. Sediment. Petrol., 52, 279-297.

増田孝一郎, 1957 : 仙台北部, 七北田層下部についての一考察. 地質雑, 63，704-710.

McCave. I. N., 1971 : Sand waves in the North Sea off the coast of Holland. Marine Geol., 10, 199-225.

中川久夫・蟹沢聰史・永広昌之・長谷川四郎, 1989 : 総説. 生出 慶司・中山久夫・蟹沢聰史（編）日本の地質 2 東北地方,
1-6, 共立出版株式会社, 東京.

中山尚美 - 増田富士雄, 1987 : 房総半島, 更新統上総層群市宿層 の海流堆積相. 地質雑, 93, 833-845.

Oda, M., Hasegawa, S., Honda, N., Maruyama, T. and Funayama, M., 1984 : Integrated biostratigraphy of planktonic foraminifera, calcareous nannofossils, radiolarians and diatoms of Middle and Upper Miocene sequences of Central and Northeast Honshu, Japan. Palaeogeogr. Palaeoclimatol. Palaeoecol., 46, 53-69.

Ramsay, P.J., Smith, A.M. and Mason, T.R., 1996 : Geostrophic sand ridge, dune fields and associated bedforms from the Northern KwaZulu-Natal shelf, south-east Africa. Sedimentology, 43, 407-419.

Saito T. and Isawa T., 1995 : Planktonic foraminifers of Late Miocene age (zone N.17) from the Aoso Formation of Sendai City, northeastern Honshu, Japan. Saito Ho-on Kai Mus. Nat. Hist, Res. Bull., no. 63, 9-23.

斎藤文紀, 1989 : 陸棚堆積物の区分と暴風型陸棚における堆積 相. 地学雑, 98, 350-365.

高野 修・保柳康一・能登正明・太田勝一・八幡正弘・樺戸団 研堆積相グループ, 1995 : 北海道樺戸山地南部における新第 三系の斜面〜陸棚〜ファンデルタ〜礫質河川システム. 地球 科学, 49, 253-270.

鳥越祐司, 1992 : 仙台市北方に分布する志田層群上部の層序执よ び堆積環境. 日本地質学会第 99 年学術大会講演要旨, 201 .

Walker, R.G. and Plint, A.G., 1992 : Wave-and stormdominated shallow marine systems. In Walker, R. G., ed., Facies models : response to sea level change, 219-238, Geol. Ass. Can.

柳沢幸夫 ・秋葉文雄, 1999 : 松島地域の中新世珪藻化石層序の再 検討．地調月報， 50，431-448. 


\section{宮城県仙台市北方の上部中新統番ヶ 森山層, 青麻層の海流堆積相}

吉田 真見子·立石 雅昭, 2003, 堆積学研究, No. 56, 27-39

Yoshida, M. and Tateishi M., 2003 : Ocean current-dominated sedimentary facies of the Upper Miocene Bangamoriyama and Aoso Formations to the north of Sendai, Miyagi Prefecture, Northeast Japan.

Jour. Sed. Soc. Japan, No. 56, 27-39

宮城県仙台市の北方地域には, 大型斜交層理の発達した上部中新統の志田層群番ヶ森山層・ 青麻層が分布している，この番ヶ森山層・青麻層，およびその上下に不整合関係で重なる入菅 谷層・七北田層に扔いて堆積相解析を行った。 その結果, 11 の堆積相と 3 つの堆積組相 （WS・OS・GS）を認定した。堆積組相はそれぞれ波浪卓越型陸棚システム（WS）・海流卓 越型陸棚システム $(\mathrm{OS}) \cdot$ 重力流卓越型陸棚システム $(\mathrm{GS})$ を示している。これらから, 番ヶ森山層・青麻層は一方向性の海流により形成された堆積物であることがわかった。そし て, 番ヶ森山層・青麻層堆積期の仙台周辺地域は, 阿武隈山地と北上山地に挟まれた海峡部に 位置し，この海峡に南西から暖流の分岐が流れ込んでいたことを復元した。 